\title{
Salt (NaCl) use in New Zealand pastoral agriculture - a summary of recent trial results
}

\author{
M.F.HAWKE ${ }^{1}$, M.B.O'CONNOR ${ }^{2}$, J. WALLER ${ }^{2}$, K.A.MACDONALD ${ }^{3}$, B. HOBSON ${ }^{4}$ and S.COULTER ${ }^{4}$ \\ ${ }^{1}$ AgResearch, Private Bag 3020 Rotorua \\ ${ }^{2}$ AgResearch, Ruakura, Private Bag 3123 Hamilton \\ ${ }^{3}$ Dexcel, Private Bag 3221, Hamilton \\ ${ }^{4}$ Dominion Salt Ltd, Private Bag 4249, Mt Maunganui South \\ martin.hawke@agresearch.co.nz
}

\begin{abstract}
Milking cows in mid-season gave a $12.8 \%$ increase in milk yield when drenched with $\mathrm{NaCl}$ where herbage sodium (Na) levels were deficient $(<0.05 \%)$, whereas at a herbage Na level of $0.10 \%$ in February, there was no milk yield response to salt supplementation. Dairy heifers growing at 1.0-1.6 kg liveweight gain/head/day at a herbage $\mathrm{Na}$ level of $0.05 \%$ and ad libitum pasture did not benefit from salt supplementation using salt blocks. An application of $100 \mathrm{~kg} \mathrm{NaCl} /$ ha salt to pasture maintained $\mathrm{Na}$ levels in pasture for 5 months but in severely deficient situations up to $180 \mathrm{~kg} / \mathrm{ha}$ may be required.
\end{abstract}

Dusting pastures with salt or a salt/MgO combination prior to calving resulted in elevated herbage $\mathrm{Na}$ and magnesium $(\mathrm{Mg})$ status from the dust adhering to the grass for up to 5 days after application. Mixing the two products improved handling and reduced the drift of dust when applied to the paddock.

There is a range of methods for supplementing animals with sodium, all of which have their place, depending on the type of livestock enterprise.

Keywords: dairy cows, dairy heifers, pasture, salt blocks, salt dusting, sodium

\section{Introduction}

Sodium (Na) is an essential element for animals but is not essential for plants. Dairy cows routinely expel $\mathrm{Na}$ from the body in urine, faeces, saliva and milk which needs to be replaced. At the same time, soil reserves of Na seem to be declining (O'Connor, unpublished data). Recent results suggest leaching of $\mathrm{Na}$ from pastoral soils is quite significant at between 30 and $80 \mathrm{~kg} / \mathrm{ha} /$ year whereas inputs from rainfall are generally around $30 \mathrm{~kg} /$ ha/annum leaving an overall deficit in many situations (Rajendram et al. 1998). Animals can be supplemented with salt either directly through drenching, salt blocks, licks or water trough, or indirectly by applying it to pasture as a fertiliser. Some plants e.g. white clover and ryegrass readily take up $\mathrm{Na}$ (natrophiles) but others like lucerne, browntop and kikuyu (natrophobes) have low rates of uptake. Excellent responses to $\mathrm{Na}$ supplementation of animals grazing lucerne have been obtained (Joyce et al.1975) while responses on ryegrass-clover pastures, although less common, have been obtained on the Central Plateau (Smith \& Middleton 1978; O'Connor et al. 2000) and in inland Marlborough (Dominion Salt Ltd. pers.comm.).

In New Zealand, inland soils in particular are low in $\mathrm{Na}$. This includes the Central Plateau pumice soils of the North Island and the associated volcanic soils of the Waikato/King Country and soils of inland Marlborough, Canterbury, Otago and Southland in the South Island. Increased dairy production, animal stocking rates and/or the use of potassium fertilisers have contributed to a decrease in the Na status of these and other soils throughout New Zealand.

It is important to demonstrate on $\mathrm{Na}$ deficient soils and in intensive dairying systems whether supplementation with salt will improve livestock performance and milk production. It is also important to test new products and evaluate their performance.

This paper summarises results from a range of trials on sodium supplementation and product development during the past 3 years.

\section{Trial details and results}

\section{Salt supplementation of dairy cows at Rotorua}

This trial was conducted by O'Connor et al. (2000) during spring/summer of 1999/2000 on a dairy farm at Waikite, near Rotorua. The soil type was Atiamuri sandy silt, an orthic pumice soil, and the initial herbage analysis was $0.02 \% \mathrm{Na}$. Ninety cows were grouped into 45 pairs, based on breed, age, calving date and previous milk production. The animals in a pair were randomly allocated to either a drenched group (14g Na/cow/day) or an undrenched control.

Measurements included fortnightly milk production, fat and protein analysis, saliva analysis for $\mathrm{Na}$ and $\mathrm{K}$ and pasture $\mathrm{Na}$ analysis.

There was a significant milk yield response over the trial period of $12.8 \%$ but no effect on milkfat or protein concentrations (Figures 1 and 2). Herbage concentrations averaged $0.05 \% \mathrm{Na}$ (range $0.02-0.07$ ) for the period of the trial over the range of paddocks and soil types of the farm. Saliva Na:K ratios were significantly greater in cows being supplemented with salt (O'Connor et al. 2000). 
Figure 1 The effect of salt supplementation on milk yield.

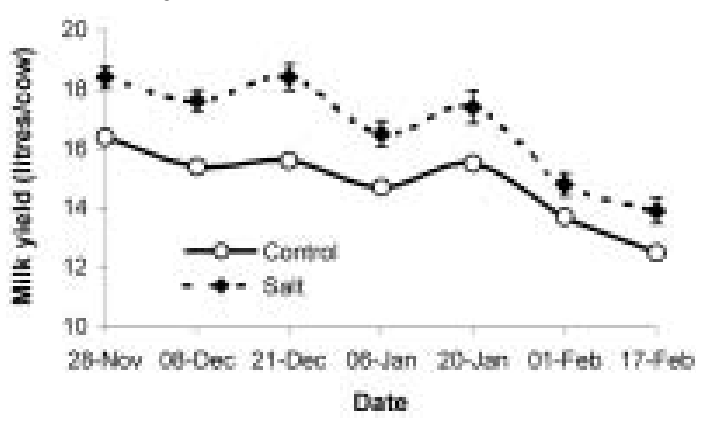

\section{Salt supplementation of lactating dairy cows at}

\section{Ruakura}

This short term (4 week) trial was conducted by Macdonald et al. (2002) during summer, 2001, superimposed over a ten farmlet stocking rate trial at No.2 Dairy, Dexcel on pastures with $0.10 \% \mathrm{Na}$. One hundred and eighty-eight cows were randomly allocated to a control and $\mathrm{Na}$ supplement treatment, such that there was an even distribution of age, genetic merit and preexperimental milk and milksolids production.

Milk volume for each cow was measured weekly and a sub-sample was analysed to determine milkfat, milk protein and milksolids production. Blood samples were collected from 54 cows to determine magnesium $(\mathrm{Mg})$, calcium $(\mathrm{Ca})$ and potassium $(\mathrm{K})$ concentration and pasture samples were analysed for nutritive characteristics and mineral concentrations.

Supplementation of Na had no significant effect on milk yield (Table 1), milkfat, milk protein or milksolids and there was no significant interaction of herd with salt treatment. Supplementation decreased blood K concentration (Macdonald et al. 2002).

Table 1 Yield of milk, milkfat, milk protein and milksolids in mid lactation supplemented with either 0 or $14 \mathrm{~g} \mathrm{Na}$ daily for 3 weeks.

\begin{tabular}{lccc}
\hline & $\begin{array}{c}\text { Control } \\
(0 \mathrm{~g} \mathrm{Na} / \text { day })\end{array}$ & $\begin{array}{c}\text { Treatment } \\
(14 \mathrm{~g} \mathrm{Na} / \text { day })\end{array}$ & SED \\
\hline Milk & 11.1 & 11.1 & 0.16 \\
Milkfat & 0.53 & 0.53 & 0.010 \\
Milk protein & 0.38 & 0.38 & 0.005 \\
Milksolids & 0.91 & 0.91 & 0.014 \\
\hline
\end{tabular}

\section{Rates of agricultural salt applied to pastures}

Salt ( $40 \%$ Na content) was applied by truck at 4 rates $(0$, 50,100 and $180 \mathrm{~kg} / \mathrm{ha}$ ) in October, 2000 to a selection of paddocks on the Waikite property. The salt used had $41.8 \%$ above $5.6 \mathrm{~mm}$ particle size. Two paddocks per salt application rate and one control (no salt) paddock were sampled for herbage $\% \mathrm{Na}$ at monthly intervals from November 2000 to March 2001.

There was an incremental increase in herbage $\% \mathrm{Na}$
Figure 2 The effect of salt supplementation on milkfat and protein content.

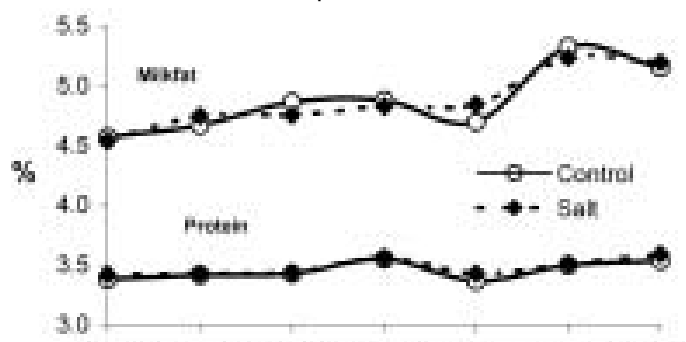

28-Nor 0B-Dec 21-Cec Oe-Jan 20-Jan 01-Feb 17-Feb Date

with increasing rates of salt. This increase was evident in November after the October salt application (Figure 3 ). The $100 \mathrm{~kg} / \mathrm{ha}$ rate peaked in November and the 180 $\mathrm{kg} / \mathrm{ha}$ rate in December.

The rates effect was evident up to 5 months after salt application. The high salt rate of $180 \mathrm{~kg} / \mathrm{ha}$ maintained the sodium herbage level at the adequate concentration of $0.12 \% \mathrm{Na}$ (Towers \& Smith 1983) throughout the period, but the effect of $100 \mathrm{~kg} / \mathrm{ha}$ declined below the adequate level after 3 months and the $50 \mathrm{~kg} / \mathrm{ha}$ rate was always below the adequate level.

\section{Salt dusting to pastures}

Trials were conducted during winter/spring of 2000/2001 on Rotorua dairy farms to investigate the ability of fine salt dust to adhere to pasture, and also the effect of applying a salt and magnesium oxide $(\mathrm{MgO})$ dust mixture on the $\mathrm{Na}$ and $\mathrm{Mg}$ available to animals eating such pasture.

In a randomised small plot trial in September, 2000 on a dairy farm near Rotorua, $\mathrm{NaCl}$ and $\mathrm{MgO}$ dusts (22 and 60 mesh respectively) were applied to autumn/winter saved pasture at four rates of $\mathrm{NaCl}(0,90,180$ and $360 \mathrm{~g}$ salt/cow/day) and two rates of $\mathrm{MgO}(0$ and $60 \mathrm{~g} / \mathrm{cow} /$ day). The salt plus $\mathrm{MgO}$ treatments were applied as a mixed product. Rates were calculated on the basis of 75 cows/ha and the assumption that two-thirds of the product applied was lost (Young et al. 1981). The products were applied in the early morning between 0630-0800 hours when the pasture was subject to heavy dew. Plot samples for $\mathrm{Na}$ and $\mathrm{Mg}$ herbage analysis were taken between 0700 and 0830 hours at 1, 3 and 5 days after application.

There was a significant increase in herbage $\mathrm{Na}$ levels with increasing rates of salt at all sampling days after application (Figure 4). Rates from 0 to $360 \mathrm{~g}$ salt/cow/ day gave incremental increases in $\% \mathrm{Na}$ in the pasture. Where a salt/MgO mix was applied, increases in herbage $\mathrm{Na}$ levels across rates were of a similar order to where salt was applied alone and herbage $\mathrm{Mg}$ levels did not decline as a result of being mixed with salt (data not shown). 
Figure 3 Effect of rates of salt on herbage $\mathrm{Na} \%$ over time (vertical bars show SED).

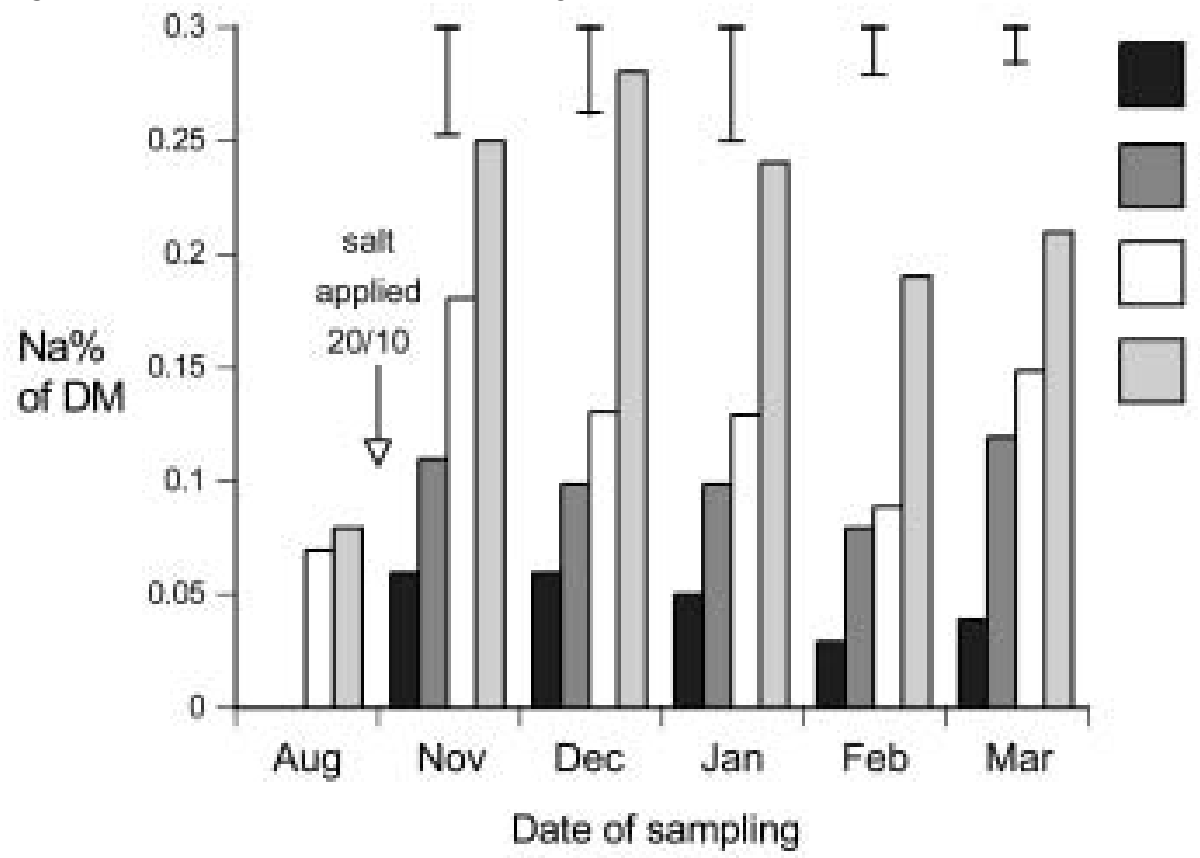

o kg saitha $50 \mathrm{~kg}$ saltha $100 \mathrm{~kg}$ saltha $180 \mathrm{~kg}$ saltha

Figure 4 Effect of increasing rates of salt on herbage $\mathrm{Na} \%$.

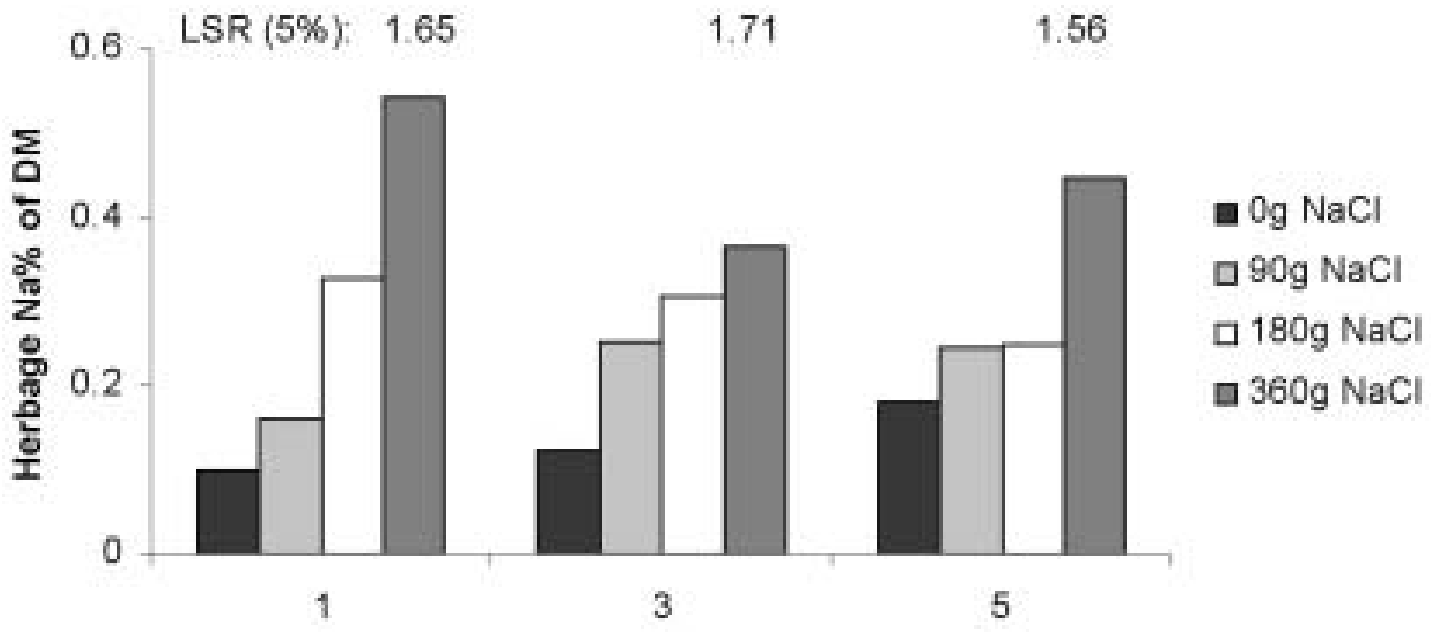

Day of sampling after application

Further research on product formulation resulted in two farm scale randomised plot trials being conducted during July, 2001. The trials compared two products ( $\mathrm{MgO}$ dust and $\mathrm{MgO} / \mathrm{Salt}$ mix) spread with the farmer's equipment and a no product control treatment. One trial was on Wharenui, a dairy farm near Rotorua, the other on Waeranga, a dairy farm near Hamurana. Herbage samples were again taken at 1,3 and 5 days after application for $\mathrm{Na}$ and $\mathrm{Mg}$ analysis.

In these field trials, there was a significant increase in herbage Na levels with the mixed product compared with control at both sites on all sampling days after application (Figures 5 and 6). Herbage $\mathrm{Mg}$ levels increased at both sites where $\mathrm{MgO}$ dust was used on its own but there was a reduction with the mixed product at one site (data not shown). 
Figure 5 Effect of salt/MgO dust on herbage $\mathrm{Na} \%$ at Wharenui.

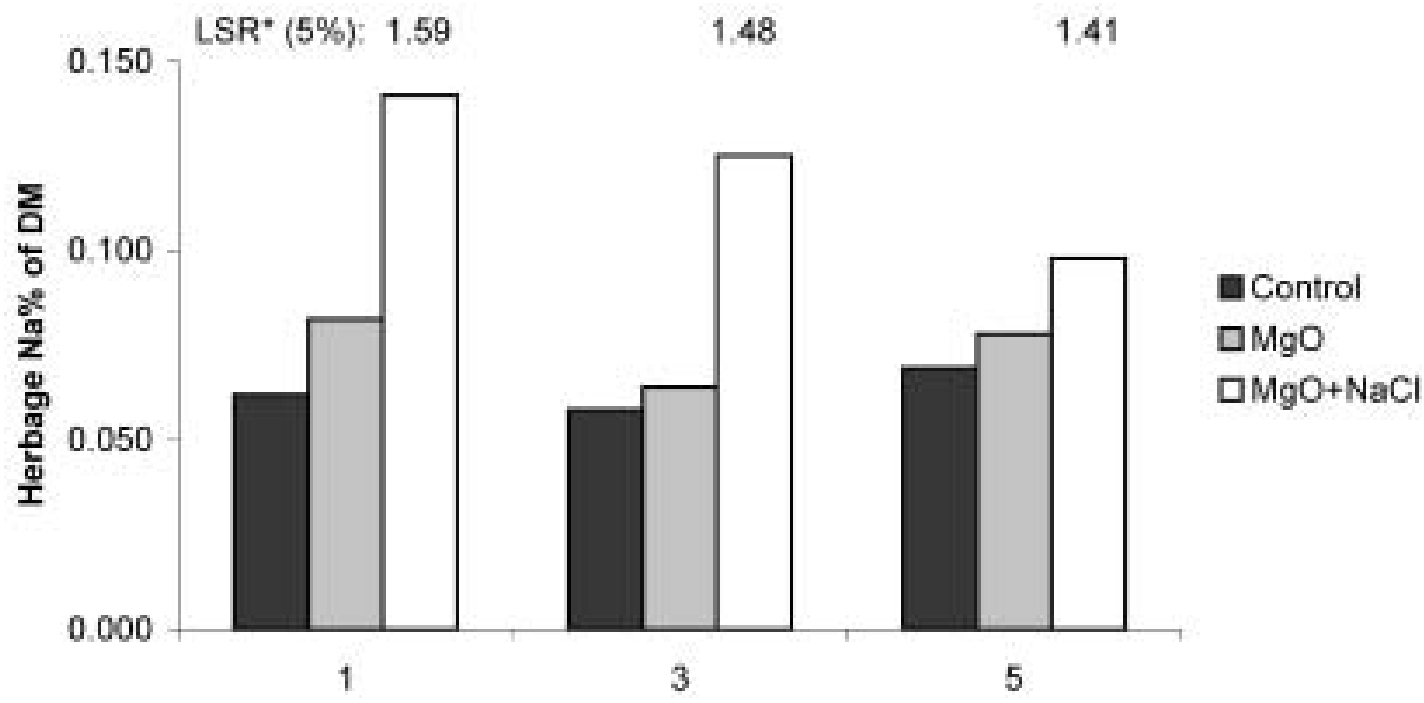

Day of sampling post application

$* \mathrm{LSR}$ is the least ratio which is statistically significant.

Figure 6 The effect of salt/MgO dust on herbage $\mathrm{Na} \%$ at Waeranga.

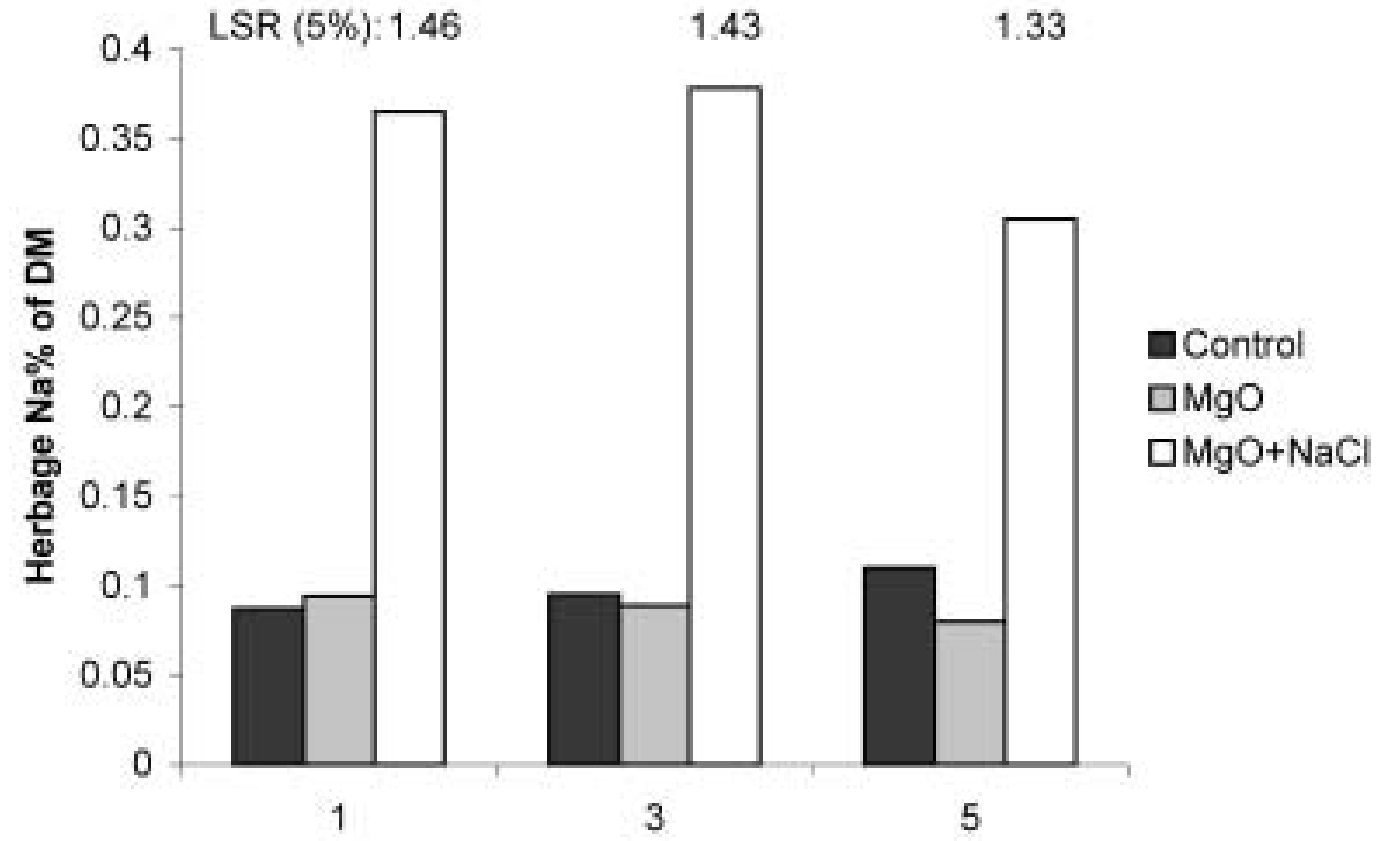

Day of sampling after application

\section{Salt block supplementation to cattle}

This trial was conducted on Lochinver Station, a large sheep/beef property near Taupo on a coarse orthic pumice soil, during spring/summer, 2001/2002. A mob of 400 replacement dairy heifers was randomised into four groups of 100 animals. Two groups were supplemented with salt blocks ad libitum. while the other two groups remained as controls. Two groups (1 with salt and 1 without) were rotationally grazed on one set of paddocks comprising predominantly ryegrass and white clover 
while the other two groups were rotationally grazed on a different set of paddocks made up of Yorkshire fog and browntop. The trial commenced on September $28^{\text {th }}$. Animals were individually weighed at approximately monthly intervals and the final weighing was on $7^{\text {th }}$ February. A selection of paddocks being grazed was sampled for herbage $\% \mathrm{Na}$ at the commencement of the trial and after 3 months. The initial range of herbage $\%$ $\mathrm{Na}$ was $0.03-0.07$.

Salt blocks were offered to the salt groups in troughs with a fresh batch of blocks offered each week. Ten salt blocks were offered per 100 animals. The used blocks were weighed each week to calculate the average salt usage per animal per day. Two salt blocks were placed in a trough in a no-treatment area (no grazing) and weighed at weekly intervals for erosion rates. Pasture dry matter (DM) was assessed at weekly intervals from the next paddock to be grazed by each mob by taking fifty meter readings using a Farm Tracker electronic rising plate meter.

There was no significant difference in daily liveweight gain per animal between the control (no salt) and the salt groups for the first three periods of the trial (Table 2). In the fourth period, there was a significant $(\mathrm{P}<0.05)$ response to the salt group, which was entirely due to one mob of animals.

Table 2 Average liveweight gain ( $\mathrm{kg} / \mathrm{animal} /$ day) at Lochinver.

\begin{tabular}{lcccc}
\hline Period & Days & $\begin{array}{c}\text { Control } \\
\text { (no salt) }\end{array}$ & Salt & LSD(5\%) \\
\hline 28th Sep-26th Oct & 28 & 1.69 & 1.65 & 0.07 \\
26th Oct-29th Nov & 34 & 1.25 & 1.33 & 0.09 \\
29th Nov-10th Jan & 42 & 1.00 & 0.92 & 0.09 \\
10th J an-7th Feb & 28 & 0.91 & 1.16 & 0.17 \\
\hline
\end{tabular}

There was an average mixed herbage Na level of $0.05 \%$ at the start of the trial, but this had risen to $0.09 \%$ after the third month. There was no substantial difference in pasture DM on offer between groups within any of the periods. Salt usage from the blocks varied between weeks from $30-100 \mathrm{~g} \mathrm{NaCl} / \mathrm{head} /$ day.

\section{Discussion}

\section{Milk yield responses}

The yield response at the Waikite trial was immediate (Figure 1) and it continued throughout the trial. This was a mid-season response and there was an indication that the higher- producing cows responded better than the lower- producing cows. Based on milk solids payouts and costs in 2000, there was an additional $\$ 129.90 / \mathrm{cow}$ income and a cost for the salt of $\$ 2.94 /$ cow. In contrast, there was no response at the Ruakura trial, conducted in the latter part of the lactation and no indication of cow performance differences.
A comparison of the results suggests that at Ruakura, $\mathrm{Na}$ intake was sufficient for the level of milk production, whereas at Waikite, $\mathrm{Na}$ intake was insufficient for optimum production. The stage of lactation in the Ruakura trial (180 days) and the lower pasture growth and quality resulted in a drop off in milk production and the outgoing Na in the milk may not have been sufficiently high enough for the cows to require supplementation (Macdonald et al. 2002). The latter part of the Waikite trial was also in February when milk yield responses to salt showed a slight fall off (Figure 1).

\section{Sodium content of pastures}

The two milk production trials at Waikite and Ruakura had average $\mathrm{Na}$ concentrations of $0.05 \%$ and $0.10 \%$, respectively. The pasture at Waikite was deficient in $\mathrm{Na}$ throughout the trial duration whereas the Ruakura site was marginally deficient, particularly for higher producing animals.

In the salt block trial at Taupo, herbage $\mathrm{Na}$ concentrations were also deficient at $0.05 \%$, but the lower $\mathrm{Na}$ requirement of dairy heifers and the amount of feed on offer suggested that the animals were receiving adequate sodium. Absorption of $\mathrm{Na}$ in the animal may have been higher than is normally expected due to the good feed quality, causing less loss through dung and urine.

A comparison of the sites suggests that knowledge of herbage $\mathrm{Na}$ concentrations, together with the class of stock, herbage availability and quality are needed to determine if a Na response can be forecast. Responses are likely only in the most extreme circumstances.

\section{Sodium dusting of pastures}

Dusting pastures with salt or a salt/MgO mix was a satisfactory way of supplementing the intake of sodium at calving time and early in the lactation. The salt dust was easy to handle and when mixed with $\mathrm{MgO}$, it reduced the drift of dust. This is seen as a definite advantage to the farmer. Rainfall should be monitored because in the first trial (September, 2000), there was negligible rainfall $(0.5 \mathrm{~mm}$ on day 3$)$ and elevated herbage $\mathrm{Na}$ concentrations were measured at day 5 . In the second set of trials (July, 2001), $11 \mathrm{~mm}$ rain fell between days 3 and 5 and there was a reduction in herbage $\mathrm{Na}$ concentrations at day 5. Results were similar with $\mathrm{Mg}$.

On a farm scale (second set of trials), there was some evidence that where salt was mixed with $\mathrm{MgO}$ and at the rates used, Mg herbage levels were reduced, although they were still adequate (data not shown).

\section{Salt block supplementation}

Animals grew well in the trial, generally averaging $>1$ $\mathrm{kg} /$ day LW gain. Calculations suggest they would be consuming at least $10.4 \mathrm{~kg} \mathrm{DM} /$ day to sustain such gains 
(Smeaton, pers comm). At $1 \mathrm{~kg} \mathrm{LW}$ gain/day animals would require $4 \mathrm{~g} \mathrm{Na} /$ animal. Average September pasture levels were $0.05 \% \mathrm{Na}$ and January levels $0.09 \% \mathrm{Na}$. An intake of $10.4 \mathrm{~kg}$ DM would supply $5 \mathrm{~g} \mathrm{Na} /$ animal/day using September pasture levels and $9 \mathrm{~g} /$ day for January levels. Both are more than adequate for the animal performance achieved. There was no explanation for the liveweight gain response in the fourth period to one mob of animals as all measurements indicated adequate pasture levels. However, the provision of salt is an inexpensive insurance policy if there are concerns of sodium deficiency.

Further research is suggested for dry summer situations (Lochinver had a wet summer in 2001/02) where feed quantity and/or quality may be less and $\mathrm{Na}$ intake deficient or where $\mathrm{Na}$ may be providing an enhanced feed intake (Chiy et al. 1993).

\section{Methods of salt supplementation}

For the milking dairy cow, drenching is considered the most effective method as each cow will receive the daily requirement. Salt dusting of pastures prior to calving is a practical method with an added benefit that it can be mixed with magnesium oxide dust. On sheep/beef farms, salt blocks are a convenient method of $\mathrm{Na}$ supplementation or salt can be included in a multimineral block. Applying salt evenly to pasture from a fertiliser hopper is an inexpensive and practical way of lifting herbage $\mathrm{Na}$ levels for several months.

\section{Conclusions}

Responses to Na supplementation are dependant on several factors: the Na concentration in the pasture, the class of stock and their production levels, the time of year, and the quantity and quality of feed on offer.

Where herbage was deficient in sodium, there was a milk yield response to salt supplementation, particularly in mid-lactation. Dairy heifers had a lower requirement for salt that was met by their herbage intake, despite low initial herbage Na levels. Salt applied to pastures at 100 $\mathrm{kg} / \mathrm{ha}$ maintained herbage $\mathrm{Na}$ levels for 5 months.

All methods of Na supplementation have a place and the recent product development with salt dust suggests it is a satisfactory method of providing $\mathrm{Na}$ for dairy cows at calving time.

\section{ACKNOWLEDGMENTS}

To the staff at Lochinver Station, Wharenui and Waerenga for their cooperation and their assistance with the trials.

\section{REFERENCES}

Chiy, P.C.; Phillips, C.J.C.; Bello, M.R. 1993. Sodium fertilizer application to pasture. 2. Effect on dairy cow production and behaviour. Grass and Forage Science $48: 203$.

Joyce, J.P.; Brunswick, L.C.F. 1975. Sodium supplementation of sheep and cattle fed lucerne. New Zealand Journal of Experimental Agriculture 3: 299304.

Macdonald, K.A.; Lile, J.A.; Lancaster, J.A.S.; Coulter, M.; O'Connor M.B. 2002. Salt supplementation of lactating dairy cows. Proceedings of the New Zealand Society of Animal Production 62: 236-239.

O'Connor, M.B.; Hawke, M.F.; Waller, J.E.; Rotheram, J.R.; Coulter, S.P. 2000. Salt supplementation of dairy cows. Proceedings of the New Zealand Grassland Association 62: 49-53.

Rajendram, G.S.; Ledgard, S.F.; Monaghan, R.; Penno, J.W.; Sprosen, M.; Ouyang,L. 1998. Effect of rate of nitrogen fertiliser on cation and anion leaching under intensively grazed dairy pasture. pp. 67-74. In: Longterm nutrient needs for New Zealand's primary industries: global supply, production requirements and environmental constraints. Eds. Currie L.D; Loganathan P. Occasional Report No. 11. Fertiliser and Lime Research Centre, Massey University, Palmerston North.

Smith, G.S.; Middleton, K.R.1978. Sodium and potassium content of topdressed pastures in New Zealand in relation to plant and animal nutrition. New Zealand Journal of Experimental Agriculture 6: 217-225.

Towers, N.R.; Smith, G.S.1983. Sodium (Na). pp.115124. In: The mineral requirements of grazing ruminants. Ed. Grace, N.D. New Zealand Society of Animal Production Occasional Publication No. 9.

Young, P.W.; Rys, G.; O'Connor, M.B. 1981. Hypomagnesaemia and dairy production. Proceedings of the New Zealand Society of Animal Production 41: 61-67. 